\title{
Протестное движение рабочих в России в годы Первой мировой войны (Читая книгу Ю. И. Кирьянова)
}

\begin{abstract}
Аннотаиия: В статъе анализируется книга Ю. И. Кирьянова, посвященная рабочему движению в России в годъ Первой мировой войнъ. Автор рассматривает историографию вопроса и релвефно показывает то проблемное пространство, которое после выхода книги Ю. И. Кирьянова стало выглядеть значительно измененнъм. Многие вопросы истории рабочего движения, считавшиеся прежде изученными, получили благодаря исследованию Ю. И. Кирьянова новое освещение. Ю. И. Кирьянов досконально проверил данные тех источников, на основании которых сложилась послереволюиионная историография данной проблемь, иубедительно показал необходимость уточнения многих закрепившихся в исторической науке выводов о рабочем движении предреволючионной эпохи. Автор разбирает книгу Ю. И. Кирьянова, опираясь на результатъ собственнъхх исследований темъ, которые отражены в нескольких работах. Отдельное внимание в статъе уделяется полемике с новейшими работами по истории Первой мировой войны и Февральской револючии, авторы которых затрагивают вопросы рабочего движения. По мнению автора, эти исследователи не уделяют должного внимания иелому ряду сочиальнъх аспектов массовых протестных движений в годы Первой мировой войны.
\end{abstract}

Annotation: The article analyzes the book of Y. I. Kiryanov on the labor movement in Russia during the years of World War I. The author examines the historiography of the given question and details the context of the question, which was significantly altered after the publication of Y. I. Kiryanov's book. Many questions on the history of the labor movement that were considered to be well-studied, received new light through Y. I. Kiryanov's research. $Y$. I. Kiryanov thoroughly verified the data of the sources on which the post-Revolution historiography based the study of this question and convincingly showed the need to corroborate many enduring in historical science conclusions regarding the labor movement of the pre-Revolution era. The author discusses the book of Y. I. Kiryanov based on the results of his own research of this topic, which have been reflected in several works. The article gives special attention to a debate with the newest works on the history of World War I and the February revolution, the authors of which touch upon the question of the labor movement. According to the author, these scholars are not giving due attention to a whole array of social aspects of the mass-protest movements in the years of the World War I.

Ключевые слова: Первая мировая война, Февральская револючия, Государственная дума, рабочее движение, стачки, забастовки, историография, большевики, менвшевики, продовольственный кризис.

Key Words: World War I, February revolution, State duma, labor movement, strikes, protest, historiography, Bolsheviks, Mensheviks, food supply crisis.

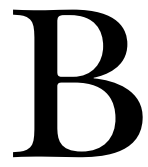
памятный для России 2014 год - год 100-летия с начала Первой мировой войны - книжные полки библиотек и Интернет пополнятся большим количеством работ, связанных с этой датой. Похоже, однако, что тема протестного движения рабочих в России - важная событийная составляющая комплекса проблем социальной и ментальной истории Первой мировой войны - останется вновь маргинальной, какой и была в течение двух последних десятилетий в нашей науке ${ }^{1}$. Вот

1 При общей численности населения в России на январь 1914 г. в 175,1 млн. человек (без Финляндии) рабочие, за- почему книга «Социально-политический протест рабочих России в годы Первой мировой войны» (июль 1914 - февраль 1917 гг.) безвременно ушедшего от нас Ю. И. Кирьянова, не получившая должной оценки в научном сообществе, заслуживает особого внимания ${ }^{2}$. Над ней ученый

нятые в сфере разных производств, составляли примерно $10 \%$ - 18,2 млн. человек. Если учесть семьи рабочих из 3-4 человек, то этот слой в общем составе населения составлял примерно 1/5 ее населения. См.: Россия. 1913 год. Статистикодокументальный справочник. СПб., 1995. С. 18-22.

2 Кирьянов Ю. И. Социально-политический протест рабочих России в годы Первой мировой войны (июль 1914 - февраль 1917 гг.) / Отв. ред. С. В. Тютюкин. М., 2005. 
Историография и источниковедение

DOI: $10.7256 / 2222-1972.2014 .3 .13745$

начал работать во второй половине 1980-х гг., но начавшийся в 1990-е гг. кризис в исторической науке изменил его планы. В начале 2002 г., перед неожиданной кончиной, он приступил к переработке рукописи, но многое не успел осуществить. Книга была издана в 2005 г. его коллегами. Автор не успел до конца сформулировать общую концепцию работы. Но главное в ней - собранный массив фактического материала, статистические таблицы, в которых на представительном объеме данных раскрыто протестное рабочее движение в годы войны, дорого обходившееся царизму и буржуазии потерянными рабочими днями в промышленном производстве. Книга Ю. И. Кирьянова дает возможность напомнить о событиях, происходивших во время войны в тылу России и определивших в конечном итоге ее судьбу. Она стала актуальной в связи с необходимостью опровержения выводов тех исследований, которые игнорируют роль рабочего России в победе демократической революции в феврале 1917 г.

\section{«У истоков Февральской революции - пролетарская стачка»}

Эта фраза из статьи 1927 г. в журнале «Пролетарская революция» ${ }^{3}$ указывает на исходное положение в советской историографии в решении сложнейших вопросов социально-политического протестного движения в России в годы Первой мировой войны. Для его обоснованности внимание историков - марксистов в первую очередь - было обращено к забастовочной борьбе как наиболее динамичной из всех проявлений общественной активности. В начале 1920-х гг. были изданы «Своды фабричной инспекции» со статистикой стачечного движения. К «Сводам» стали прибегать не только историки, но и экономисты $^{4}$, часто пользуясь и книгой М. Г. Флеера с результатами обработки показателей фабричной инспекции, а также данных о стачках на предприятиях, подведомственных горной инспекции ${ }^{5}$.

\footnotetext{
3 Яковлев Я. А. Февральские дни 1917 г. // Пролетарская революция. 1927. № 2-3. С. 75.

4 Яковлева К. Н. Забастовочное движение в России за 18951917 гг. // Материалы по статистике труда. Вып. 8. М., 1920; Статистический сборник за 1913-1917 гг. // Труды ЦСУ. Т. VII. Вып. 1. М., 1921; Фабрично-заводская промышленность в период 1914-1918 гг. М., 1923; Россия в мировой войне. 19141918. (В цифрах). М., 1925; Струмилин С. Г. Проблемы экономики труда. М., 1926.

5 Рабочее движение в России в годы войны / Подг. к печати: М. Г. Флеер. М., 1925; Флеер М. Г. Рабочее движение в России в годы империалистической войны. Л., 1926.
}

В 1967 г. материалы М. Г. Флеера вошли в трехтомную монографию академика И. И. Минца ${ }^{6}$, в 1982 г. - в обобщающий труд о рабочем классе ${ }^{7}$. В 1964-1972 гг. ленинградские историки уточнили сведения о числе забастовщиков в Петрограде с 23 по 28 февраля 1917 г. ${ }^{8}$. Получалась объемная картина забастовочного движения. Но до книги Ю. И. Кирьянова не было полного представления о забастовочном движении в первый военный период до демократической революции 1917 г.

Еще в 1986 г. на коллоквиуме в г. Кортона (Италия) Ю. И. Кирьянов, сравнивая стачечное движение в годы Первой мировой войны в Петербургской и Екатеринославской губерниях, доказал, что количественные данные о стачках и стачечниках при использовании опубликованных материалов местных изданий (хроник) в 1,5 и 3 раза выше официальных «Сводов отчетов фабричной инспекции» Министерства торговли и промышленности, МВД и Особого совещания по обороне ${ }^{9}$.

Продолжая работать над статистикой стачечного движения в стране в военные годы, Ю. И. Кирьянов уточнил существовавшие в арсенале ученых показатели, обновив информацию о забастовочном движении на основе выверенного «наряда» помесячных сведений о рабочих стачках в России ${ }^{10}$.

По сбору материала для статистики забастовочной борьбы Ю. И. Кирьянов работал вместе с Г. Г. Касаровым, автором-составителем хроники «Стачки в России в 1914 - феврале 1917 гг. Хроника» (М., 1989 г.). Были просмотрены десятки местных изданий, хроники рабочего движения

\footnotetext{
6 Минц И. И. История Великого Октября. Т. 1. Свержение самодержавия. М., 1967. С. 341-352, 374.

7 Рабочий класс России. 1907 - февраль 1917. М., 1982. С. 328.

8 Крылова И. И. К вопросу о статистике стачек в годы Первой мировой войны // Из истории империализма в России. М.-Л., 1959. С. 425-429; Лейберов И. П. О революционных выступлениях петроградского пролетариата в годы Первой мировой войны и Февральской революции // Вопросы истории. 1964. № 2. С. 65; История рабочих Ленинграда. Том I. 1703 - февраль 1917. Л., 1972. С. 475-476, 492-493, 500-505, 514-515, 518, 529.

9 Kirianov Y. I. The Strike Movement in Imperial Russia during the First World War: a Discussion of Statistical Data // Annali Anno Ventisettesimo 1990/1991. Strikes, Social Conflict and the First World War. An International Perpective. P. 375-388.

10 См.: Стачечное движение в России в годы Первой мировой войны. Материалы официальной статистики за август 1914 январь 1917 гг. В 4-х выпусках / Отв. ред. В. Я. Лаверычев. М., 1987. «Наряд» фабричных инспекторов и горных инженеров использовался М. Г. Флеером, но его книга содержала некорректные перегруппировки статистики, неэкономические стачки М. Г. Флеер включал в разряд политических.
} 


\section{Исторический журнал: научные исследования № 3 (21) • 2014}

DOI: $10.7256 / 2222-1972.2014 .3 .13745$

в различных губерниях России, в которых нашел отражение период Первой мировой войны $^{11}$. Вывод сводился к тому, что по некоторым губерниям данные местных хроник превышают официальные показатели в 2-4 раза, особенно если учитывались металлургические заводы. По Петрограду повышение показателей числа стачечников составило в 1915 г. $29 \%$, в 1916 г. $-56 \%$. В целом по Центральному промышленному району (ЦПР) - 46,5\%, по Центральному черноземному (ЦЧР) $-96 \%^{12}$.

Перед контаминацией новых материалов с показателями фабричной и горной инспекции Ю. И. Кирьянов провел кропотливую работу по проверке на репрезентативность информации по каждой стачке в «Сводах фабричной инспекции» в сравнении более высокими показателями местных историков, которые часто ориентировались на воспоминания.

Книга Ю. И. Кирьянова завершила в историографии важный этап в представлении общих «количественных» показателей забастовочного движения в России, в том числе данных о политических стачках в годы Первой мировой войны, уточнила представление о масштабах и направленности стачечной борьбы в сравнении с показателями фабричной инспекции (см. таблицу).

По нашим подсчетам, сделанным на основе таблиц в книге Ю. И. Кирьянова (с. 181-192, 203-295), с 19 июля 1914 г. до 28 февраля 1917 г. в России в 5794 стачках в стране приняли участие 3 млн. 239,8 рабочих. Новые сведения о забастовках и участниках в них за первый период войны до Февральской революции 1917 г. превосходят показатели, находящиеся до сегодняшнего дня в научном обороте, соответственно в 1,9 и 1,6 раза $^{13}$.

По уточненным сведениям о политических стачках ${ }^{14}$ в 1904 случаях $(32,9 \%$ от общего чис-

\footnotetext{
11 Речь идет о материалах по Петрограду, ЦПР, ЦЧР, Северному Кавказу, Уралу, Сибири, Украине, Екатеринославской, Херсонской и Бессарабской губерниям. Новые сведения отсутствовали по ряду губерний Северо-Западного региона, Дону, Прибалтике, Закавказью, Средней Азии и Казахстану.

12 Кирьянов Ю. И. Указ. соч. С. 18.

13 В книге Ю. И. Кирьянова помесячные данные о количестве стачек и стачечников в 1914-1916 гг. даны в таблицах: А - по «Статистическому сборнику», Б - по сборнику «Рабочее движение в России в годы войны» М. Г. Флеера, В - по материалам Особого совещания по обороне, Г - по материалам ДП МВД. (См.: Кирьянов Ю. И. Указ. соч. С. 181-183). Контаминации этих количественных показателей с новым материалом по губерниям в таблицах в рукописи и архиве ученого не обнаружено, отдельные сведения имеются только в тексте книги.

14 Имеются в виду стачки: прямо или опосредованно обращенные рабочими к властям и правительству, демонстративного характера по поводу общественных и политических
}

ла) участвовали 1 млн. 183,0 тыс. рабочих (36,5\% от того же числа). В это количество включены как политические все 899 стачек и 732,7 тыс. участников в них в Петрограде с 23 по 28 февраля 1917 г. ${ }^{15}$

Эти показатели свидетельствуют о том, что забастовочная борьба рабочих в России была ударной политической силой в совершенно различных потоках совершенно «разнородных классовых интересов», которые в феврале 1917 г. «замечательно дружно слились» и «скинули обветшалую монархию» ${ }^{16}$.

Новая статистика стачечного движения в годы Первой мировой войны еще убедительнее опровергает недооценку рабочего движения как общественной силы, которая сегодня представляется в некоторых работах чем-то вроде «массовки» во время «заговоров» в «верхах», которые якобы привели к крушению самодержавной России в годы Первой мировой войны ${ }^{17}$.

Ю. И. Кирьянов не уходит от сложных вопросов, которые возникали в литературе: соотношение «голодного бунта» или социально-политического протеста, состав участников стачечного движения и др.

Лидеры рабочего движения сетовали на то, что провинциальное движение рабочих долго находилось в раздробленном состоянии. В книге отмечены пять групповых стачек в провинции (в Иваново-Вознесенске в августе 1915 г., на заводе «Наваль» в г. Николаеве в январе 1916 г., в Горловском районе Донбасса в апреле-мае 1916 г.,

событий (9 января 1905 г., Ленский расстрел 1912 г., 1 Мая). К категории политических отнесены стачки против применения властями огнестрельного оружия в ходе массовых выступлений, против ареста представителей левых партий, приостановки работы Государственной думы, реакция рабочих на поражение русских войск на фронте.

Из числа политических автором книги исключены стачки, не подходящие под эти определения неэкономического характера, в годы войны. Это стачки, содержавшие требования вежливого обращения, удаления ненавистных мастеров. К ним отнесены: невыход на работу или ее прекращение в связи с объявлением мобилизации, проводами в армию, с кампанией против немецких подданных. См.: Кирьянов Ю. И. Указ. соч. C. 34-48.

15 История рабочих Ленинграда. Т. І. 1703-1917. Л., 1972. С. 485, 492-494, 500-501, 515, 529.

16 Ленин В. И. Письма из далека. Письмо 1. Первый этап первой революции. Полн. собр. соч. Т. 31. С. 16.

17 Никонов В. А. Крушение России. 1917. Минск, 2011. «С советских времен, - сказано в этой книге, - революции ассоциируются в основном с пролетариатом, которому нечего терять, кроме своих цепей, и поэтому он идет на штурм антинародной власти, увлекая за собой вечно упиравшихся и колеблющихся попутчиков. Пролетариат был действительно активен. Но в революции он выполнил в основном роль массовки, причем не на основной сцене». См. с. 182, 412. 
Историография и источниковедение

DOI: $10.7256 / 2222-1972.2014 .3 .13745$

Таблииа

Стачечное движение в России в годы Первой мировой войны (19 июля 1914 - 23 февраля 1917 гг.)

\begin{tabular}{|l|c|c|c|c|c|c|c|c|c|c|}
\hline & \multicolumn{2}{|c|}{$\mathbf{1 9 1 4}$} & \multicolumn{2}{|c|}{$\mathbf{1 9 1 5}$} & \multicolumn{2}{c|}{$\mathbf{1 9 1 6}$} & \multicolumn{2}{|c|}{$\mathbf{1 9 1 7}$} & \multicolumn{2}{c|}{$\mathbf{1 9 1 4 - 1 9 1 7}$} \\
\cline { 2 - 11 } & $\mathbf{A}^{*}$ & $\mathbf{6} * *$ & $\mathbf{A}$ & $\mathbf{6}$ & $\mathbf{A}$ & $\mathbf{6}$ & $\mathbf{A}^{* * *}$ & $\mathbf{6} * * *$ & $\mathbf{A}$ & $\mathbf{6}$ \\
\hline Всего стачек & 70 & $170(149)$ & 963 & $1928(1854)$ & 1542 & $2417(2292)$ & 400 & 1279 нет св. & 2975 & $5794(4995)$ \\
\hline $\begin{array}{l}\text { Всего стачеч- } \\
\text { ников }\end{array}$ & 37,2 & 86,7 & 569,2 & 862,0 & 1172,6 & 1558,4 & 270,1 & 732,7 & 2049,1 & 3239,8 \\
\hline $\begin{array}{l}\text { Политиче- } \\
\text { ские стачки }\end{array}$ & 8 & 18 & 216 & 355 & 243 & 252 & 229 & 1279 & 696 & 1904 \\
\hline $\begin{array}{l}\text { Всего участ- } \\
\text { ников } \\
\text { политич- } \\
\text { ских стачек }\end{array}$ & 4,4 & 12,0 & 156,9 & 165,2 & 310,3 & 273,1 & 162,9 & $732,7 * * * *$ & 634,5 & 1183,0 \\
\hline
\end{tabular}

Примечания к таблице наши. - И. П.

* Здесь и далее в графе «А» - данные о стачках и стачечниках в тыс. В кн.: История рабочего класса СССР. Рабочий класс России. 1907 - февраль 1917. М., 1982. С. 328. (В скобках - число стачек с известным количеством стачечников.)

** Здесь и далее в графе «Б»- данные о стачках и стачечниках в тыс. В кн.: Кирьянов Ю. И. Социально-политический протест рабочих. С. 202, 203 Таблицы.

*** В графе «A» за 1917 г. - известное число стачек и стачечников с 19 июля 1914 г. и только до января 1917 г. включительно. **** В графе «Б»- сведения о политических стачках включены $и$ в общие показатели стачечного протеста с 1 января до 28 февраля 1917 г. (В показатели политических стачек вошли подсчеты автора за январь - 22 февраля 1917 г. и ленинградских исследователей за 23-28 февраля 1917 г. (Кирьянов Ю. И. Указ. соч. С. 203). Фабричные инспектора тоже, затрудняясь квалифицировать стачки по направлению борьбы в начале 1917 г., условно, как и стачки в феврале 1917 г., считали их политическими. ****** 732,7 тыс. участников политических стачек - цифра на 200 тыс. меньше, чем было принято в советской историографии (см.: Кирьянов Ю. И. Указ. соч. С. 86-93).

в г. Луганске в июле 1916 г., в Саратовской губернии в сентябре 1915 г. и в апреле 1916 г.). В 16 из 50 губерний и одной области (без Петроградской) с начала войны до февраля 1917 г. количество забастовщиков за год превосходило 20 тыс. бастующих ${ }^{18}$.

По регионам число участников стачек в эти военные годы располагается в следующей последовательности: ЦПР дал 1250,5 тыс., далее шли: Украина (283,4 тыс.), Урал (205,9 тыс.), ЦЧР (96,7 тыс.), Нижнее и Среднее Поволжье (50,14 тыс.), Кавказ и Закавказье (43,5 тыс.), Прибалтика (39,7 тыс.), Сибирь (30,7 тыс.), Северный Кавказ (26 тыс.).

Но на долю Петрограда с начала войны и до революции приходится около $1 / 3$ стачек, примерно от трети до половины стачечников в России в 1915-1916 гг. Поддержка рабочим протестам в столице стачками шла в войну из Центральной части России. Доля стачек в ЦПР составляла в разные периоды 1915-1916 гг. от 20 до $50 \%$ от общего их числа в России. Пик движения в ЦПР приходился на 1915 г., а доля стачеч-

18 Московская (553,6 тыс.), Владимирская (323,6 тыс.), Костромская (158,7 тыс.), Нижегородская (36,1 тыс.), Калужская (26, 8 тыс.), Тверская (48,16 тыс.), Тульская(52,7 тыс.), Ярославская (24,2 тыс.), Пермская (47,9 тыс.), Самарская (26,9 тыс.), Саратовская (18,7 тыс.), Область войска Донского (71,3 тыс.), Екатеринославская (135,5 тыс.), Херсонская (21,6 тыс.), Бакинская (37,3 тыс.), Эстляндская (26,6 тыс.) промышленные губернии. См.: Кирьянов Ю. И. Указ. соч. С. 185192. Подсчеты наши. - И. П. ников в этот год составляла около $2 / 3$ и до трети в 1916 г. Половина от этого числа в 1915-1916 гг. приходилась на Московскую губернию. На третьем месте с большим отрывом шла Украина, где доля стачечников составляла 5\% в 1915 г. и $12 \%$ - в 1916 г. В книге подчеркивается, что общее количество стачечников с начала войны до февраля 1917 г., составившее более 3 млн., превзошло уровень 1901-1904 гг. в шесть раз ${ }^{19}$.

Ю. И. Кирьянов в целом не отходит от существующей традиции в историографии в определении причин стачечного движения в годы войны, уделив особое внимание массовым выступлениям рабочих на почве дороговизны и нехватки продовольствия.

\section{«Мы накануне голодного дня, за которым последует голодный бунт»}

Эта тревожная фраза была произнесена депутатом Петроградской городской думы, свидетелем столкновений населения с владельцами магазинов и складов, весной 1916 г. ${ }^{20}$.

Проблема неразрывной связи социальнополитического протеста и продовольственных волнений в 1915-1916 гг. была поставлена в литературе еще в 1920-е гг., но не раскрыта так,

19 Кирьянов Ю. И. Указ. соч. С. 21; Трудовые конфликты и рабочее движение в России на рубеже XIX - начала XX вв. / Отв. ред. И. М. Пушкарева. СПб., 2011. С. 69.

20 Кирьянов Ю. И. Указ. соч. С. 133. 


\section{Исторический журнал: научные исследования № 3 (21) • 2014}

DOI: $10.7256 / 2222-1972.2014 .3 .13745$

как в книге Ю. И. Кирьянова. С привлечением архивных источников он приоткрывает историю повседневности рабочего-забастовщика, для которой существенное значение имела его зарплата.

Сокращение производства средств потребления в Первую мировую войну вызвало недостаток и дороговизну продуктов и необходимых товаров, которые стимулировались инфляцией, разрывом рыночных связей из-за перебоев в работе транспорта, разгулом спекуляции. Картины этих бедствий описаны в основном в художественной литературе. Уже зимой 1914-1915 гг. обследования местных властей обнаруживали громадные продуктовые залежи, не попадавшие на рынок и придерживаемые спекулянтами на складах пристаней и железнодорожных станций. Банки развили операции по кредитованию оптовых торговцев, предоставляя им возможность спекулировать.

Нехватка продовольствия стала поводом для беспорядков, симптоматичных для протестного движения. Вопрос сначала о мясе, сахаре, муке, позднее - об обуви, мануфактуре, керосине, спичках и др. товарах затронул прежде всего городского рабочего, превращая его из обывателя в социально просвещенную личность, задумывающуюся над положением народа в стране.

С 1915 г. до февраля 1917 г. Ю. И. Кирьяновым выявлено более 280 нестачечных выступлений, получивших резонанс в печати и зафиксированных в материалах полиции как выступления из-за нехватки продовольствия и предметов потребления рабочими и их семьями ${ }^{21}$.

Они начались с апреля 1915 г. в Петербурге и Московской губернии и были типичными для этой формы протестов. Так, 6 апреля 1915 г. в Петербурге на Смоленском рынке толпой, в которой была группа работниц ситценабивной фабрики Паля, были разгромлены мясные лавки; полиция задержала 40 человек. Нехватка мяса, сахара, жиров, повышение цен на продукты были причинами первых потасовок с торговцами. В Москве 8 апреля 1915 г. за Пресненской Заставой с выражением недовольства против выросшей дороговизны на продукты питания толпа от 3 до 5 тыс., в которой преобладали семьи рабочих, с криком «Дружно, товарищи!» начала наступать на лавки и магазины, разбивая окна и двери. В булочной и хлебопекарне товар был выкинут на улицу и растащен. Конная стража за-

21 Кирьянов Ю. И. Указ. соч. С. 133-146, 209-212. держала 6 человек. В тот день в рабочем районе Москвы за Преображенской Заставой была разгромлена булочная Воронцова ${ }^{22}$.

12 апреля 1915 г. Департамент полиции разослал всем губернаторам и градоначальникам письма по поводу ухудшающегося продовольственного снабжения, уменьшения рыночных запасов в городах и начавшейся спекуляции хлебом, мясом и другими продуктами. МВД отмечало принципиально менявшееся настроение «низших слоев общества», почувствовавших тяготы войны. Предупредить продовольственные волнения было невозможно. Они усилились в крупных городах ${ }^{23}$.

Стачки мая-июня 1915 г. с требованиями понижения цен и обеспечения продуктами питания усиливали волнения на этой почве.

7 августа 1915 г. на базаре близ Ижорского завода в с. Колпино (близ Петрограда) толпа в 2 тыс. «жен запасных и рабочих завода» с жалобами на дороговизну, подозревая, что торговцы прячут продукты с целью спекуляции, начала погром торговых помещений. Полиция применила оружие. В Нарвской, Александро-Невской частях Петрограда, за Охтой, в Петергофе толпами рабочих и других горожан 17 августа 1915 г. были разгромлены более 100 продуктовых магазинов и лавок. Произошло столкновение с городовыми и конной полицией, до 30 человек было задержано. С осени 1915 г. до февраля 1917 г. в стране не было ни одного месяца без вспышек протеста по поводу нехватки продуктов, снабжения товарами широкого потребления. В числе наиболее крупных волнений в конце 1915 г. в полицейских документах было отмечено выступление 1 октября от 1,5 до 2 тыс. женщин и подростков в Павловском Посаде Московской губернии, когда в связи с отсутствием здесь сахара были разгромлены продовольственные лавки ${ }^{24}$. 3 октября протесты из-за перебоев в продовольственном снабжении слились с крупной забастовкой 12 тыс. рабочих Глуховской мануфактуры в Богородском уезде той же губернии, которые требовали повысить заработную плату. Закончилось все на базарной площади применением оружия, двое рабочих были убиты ${ }^{25}$.

Случаев массовых возмущений из-за кризиса продовольственного снабжения и слухов по

\footnotetext{
22 Там же. С. 134-135.

23 Там же. С. 133-134.

24 Там же. С. 135.

25 Там же. С. 136, 140.
} 


\section{Историография и источниковедение}

DOI: $10.7256 / 2222-1972.2014 .3 .13745$

этому поводу «тысячи и тысячи», говорилось в одном из донесений в Департамент полиции из провинции в 1916 г. «Чины полиции, избегая возбуждения голодной и озлобленной толпы, всячески стараются не обострять обстановки» в связи с «постоянными столкновениями с нервно настроенными беднейшими слоями населения» 26 .

Рабочие начали не только чувствовать, но и осознавать неустроенность жизни - и материальную (питание, жилье, отдых), и правовую.

Реальная заработная плата «усредненного» рабочего к этому времени в связи с дороговизной упала с 252 руб. в 1914 г. до 210 руб. в 1916 г. $^{27}$

В жалобах и заявлениях рабочих называлась сумма 203 руб. в год ${ }^{28}$. В стране цены на продукты питания поднялись в среднем в 3 раза; на обувь и одежду - в 4 и более раз. Ю. И. Кирьянов отмечает, что требование повышения заработной платы в 1915 г. выдвигали $43 \%$ стачечников, в 1916 г. -54\%, а число выступлений на почве дороговизны в 1916 г. увеличилось в 14 раз ${ }^{29}$.

Городские рабочие нуждались в муке, caxape, мясе, яйцах, подсолнечном масле, картофеле, овощах, а из товаров - в табаке, мыле, обуви, ситце и других изделиях. С осени 1916 г. возмущения по поводу нехватки угля и дров переплетались с протестом против очередных мобилизационных наборов. Волнения на почве дороговизны и нехватки товаров становились массовыми. Продолжительность выступлений в 11 из известных применительно к тому времени 59 случаев составляла не один день. Ущерб от погромов определялся владельцами магазинов иногда до 1-2 млн. рублей. Из 69 известных случаев в 19 эти волнения подавлялись оружием, были убитые и раненые, десятки людей арестовывались ${ }^{30}$.

В 1916 г. выступления на почве дороговизны и нехватки продуктов отмечались в разных местах на географической карте России. С весны и далее летом (июль-август) 1916 г. многотысячные по числу участников выступления на

\footnotetext{
26 Цит. по: Граве Б. Б. К истории классовой борьбы в России в годы империалистической войны. Июль 1914 - февраль 1917 гг. Пролетариат и буржуазия. М.-Л., 1926. С. 28.

27 По данным С. Г. Струмилина. См.: Рабочий класс России. 1907 - февраль 1917. С. 262.

28 Кирьянов Ю. И. Указ. соч. С. 160.

29 Там же. С. 139.

30 Там же. С. 141-142.
}

продовольственной почве сменяли друг друга ${ }^{31}$. Многие из них получили общественный резонанс. 29 февраля - 2 марта в Ташкенте рабочим Главных мастерских Среднеазиатской железной дороги пришлось освобождать своих жен, арестованных полицией за участие в разгроме торговых лавок. В «сахарном бунте» 6 июня 1916 г. участвовали не менее 10 тыс. рабочих депо железнодорожных мастерских и членов их семей близ ст. Тихорецкая Владикавказской железной дороги, где было разграблено 14 торговых заведений.

С лета 1916 г., отмечало Отделение по охране общественной безопасности в Петрограде (ПОО), «прогрессивно возрастающая дороговизна жизни ${ }^{32}$, затруднительность приобретения продуктов первой необходимости даже в центре столицы... всей своей тяжестью легли на ютящийся на окраинах Петрограда рабочий класс».

В октябре 1916 г. в докладе ПОО подчеркивалось, что «вопросы питания в самых широких кругах населения огромной империи являются единственным и страшным побудительным импульсом, толкающим массы на постепенное приобщение к нарастающему движению недовольства и озлобления... Пока все это движение имеет строго экономическую подкладку... Но стоит только этому движению вылиться в какую-либо реальную форму... (погром, крупная забастовка, массовое столкновение низов населения с полицией и т. п.), оно тотчас же безусловно станет чисто политическим» 33 .

5 ноября 1916 г. в Самаре на базаре женщины устроили бунт, который усмиряла полиция,

\footnotetext{
31 Большое число волнений на почве дороговизны приходилось на Центральный регион (Московская, Костромская, Тверская, Нижегородская, Воронежская губернии). Многотысячные акции прокатились по Северному Кавказу и Дону (Таганрог, Кубанская, Ставропольская губернии), Урал (Вятская, Пермская губернии). Выступления прошли на Украине (Киевская, Екатеринославская, Харьковская, Черниговская, Подольская губернии), в Среднем и Нижнем Поволжье (Симбирск, Вольск, Самара), в Сибири (Красноярск, Томская, Енисейская губернии), на Кавказе (станица Тихорецкая, Сухум, Батум) и в Закавказье (Баку, Тифлис), в Средней Азии (Ташкент) и Казахстане (Оренбургская губерния, Семипалатинск). См.: Кирьянов Ю. И. Указ. соч. С. 211-213, 141-143 и др.

32 Для рабочего в столице стоимость обеда в чайной возросла в 6 раз, съемного «угла» - в 4-6 раз, сапог - в 4-5 раз и т. д. См.: Там же. С. 26-27.

33 Там же. С. 137. Прочитав в свое время эти документы, А. А. Блок заметил, что «громкого голоса» общественных настроений, «исполненных тревоги» «умирающая власть уже услышать не могла». См.: Блок А. А. Последние дни императорской власти. М., 1991. С. 15.
} 


\section{Исторический журнал: научные исследования № 3 (21) • 2014}

DOI: $10.7256 / 2222-1972.2014 .3 .13745$

арестовывая и применяя оружие ${ }^{34}$. Резолюция собрания «организованных» рабочих Самары 12 ноября 1916 г. против «расстрела голодных жен самарской бедноты» была направлена в Государственную думу. В литературе известны также многочисленные «бабьи бунты» 1916 г. с участием женщин-солдаток ${ }^{35}$.

В ноябре 1916 г. начальник Московского ГЖУ, разбираясь с причинами нехватки хлеба в губернии, отмечал, что «сразу и очень резко послышалось недовольство войной» ${ }^{36}$. Ю. И. Кирьянов, рассматривая неорганизованное и стихийное движение по поводу дороговизны в контексте работы социал-демократических организаций, пишет, что первое превалировало над результатами агитации. Жизнь подсказывала, что, отмежевываясь от погромов, низовые социал-демократические организации могли использовать недовольство народа для антивоенной пропаганды, развертывания массового политического движения против самодержавия ${ }^{37}$.

\section{Социально-политический протест как осознание рабочими необходимости революционных перемен}

Критический подход к истолкованию событий и концепций, связанных с протестным рабочим движением в годы Первой мировой войны, занимает центральное место в книге Ю. И. Кирьянова. По его мнению, издержками литературы 1930-1950 гг, а также более поздних изданий является тенденция, «приукрашивая движение», относить к политическим все стачки, возникшие в условиях военного времени, как «подрывавшие политическую основу государственного строя» ${ }^{38}$, а также считать все стачки в Петрограде в годы войны революционными ${ }^{39}$ или «носящими антивоенный характер» ${ }^{40}$.

В оправдание этих тенденций заметим, что царское правительство способствовало политизации рабочих протестов. Указом от 24 июля 1914 г. оно запрещало под угрозой трехмесячно-

\footnotetext{
34 Кирьянов Ю. И. Указ. соч. С. 137.

35 Пушкарева И. М. Февральская буржуазно-демократическая революция 1917 г. в России. М., 1982. С. 86-87.

36 См.: Кирьянов Ю. И. Указ. соч. С. 145.

37 Там же. С. 138.

38 Там же. С. 36, 102. См. также сноску 5 с указанием литературы.

39 Там же. С. 37, 103. См. также сноску 7 с указанием литературы.

40 Там же. См. также сноску 8 с указанием литературы.
}

го заключения всякого рода собрания и манифестации, «подстрекательство» к забастовкам, распространение революционной печати, пение революционных песен. Полиция получила «законные» основания арестовывать любого, вызывавшего у нее подозрения. Циркуляр МВД от 31 июля 1914 г. давал свободу действий губернским властям расправляться с участниками рабочего движения. Постановлением Совета министров от 7 февраля 1916 г. стачка наказывалась арестом, а рабочие призывного возраста - отправкой на фронт. Лозунг большевиков о превращении войны империалистической в гражданскую также способствовал политизации протестного движения.

Когда в 1980-е гг. мировое научное сообщество заговорило об изменении макроориентированной социальной истории и необходимости реконструировать макрофеномены, отправляясь от микроуровня ${ }^{41}$, Ю. И. Кирьянов практически принял это как необходимость пересмотра известных в литературе политических стачек на микроуровне, обращаясь в каждом конкретном случае к первоисточникам - архивным и мемуарной литературе. Пересмотру автором подверглись при выработанном им критерии ${ }^{42}$ стачки, названные фабричной инспекцией и в литературе политическими и антивоенными. Целью этой работы, как принято сегодня в науке, было уточнение латентной фазы социальнополитического протеста, становление консенсуса его участников (рабочих), выражавших недовольство властью на всех ее уровнях, выяснение возможности социально-политической идентификации рабочих, а применительно к февралю 1917 г. - идентификация «ударного отряда» революции.

Категорически было отвергнуто бытующее в литературе отношение к политическим или антивоенным стачкам, которые были связаны с невъходом к станку значительных групп рабочих ${ }^{43}$, с «приостановкой работ» ${ }^{44}$ на предпри-

\footnotetext{
41 Прошлое крупным планом. Современные исследования по микроистории. СПб., 2003. С. 20.

42 См. сноску 14.

43 Из категории политических выпали 26 стачек в Петербурге 19-21 июля, многие стачки в Москве, Твери, в Калужской губернии, на Урале, в Сибири, в пос. Макеевка (Область войска Донского), в Закавказье и Прибалтике. См.: Кирьянов Ю. И. Указ. соч. С. 37-48.

44 «Приостановка работ, - пояснил автор, - была продиктована боязнью рабочих потерять часть заработной платы. Эти случаи вошли в статистику для «сгущения» политической направленности рабочих протестов». См.: Там же. С. 40.
} 
ятии в связи с проводами товарищей, которые фабричная инспекция называла «бунтами новобранцев». Вывод сводился к следующему: протесты рабочих, соответствовавшие понятию «антивоенные», в начале войны и на протяжении долгих ее месяцев были единичными и проявлялись преимущественно в виде кратковременных демонстраций небольших групп рабочих, а не массовых стачек ${ }^{45}$.

Кратковременными были такие политические стачки, как реакция на арест 5 ноября 1914 г. пятерых депутатов-большевиков IV Государственной думы; 11 ноября 1914 г. четыре стачки (68 участников) типографов в Харькове, 12 ноября состоялось несколько кратковременных стачек в Петрограде. Попытки организовать рабочих на стачки по этому поводу в Москве, Сормове, в шахтах Донбасса, Екатеринославе, Владимире, Костроме, Рязани не были реализованы: рабочие дорожили местом работы и не желали быть призванными на военную службу. На некоторых предприятиях прошли лишь небольшие собрания $^{46}$. По данным фабричной инспекции, с 19 июля по 31 декабря 1914 г. в 8 политических стачках участвовали 4,4 тыс. рабочих; по уточненным автором книги сведениям - в 18 стачках участвовали 12 тыс. рабочих ${ }^{47}$.

Ю. И. Кирьянов не видел необходимости в преувеличении числа выступлений рабочих в 1915 г. в дни «традиционных» стачек (по поводу 9 января 1905 г. и др.). Он согласился с мнением столичного градоначальника, что в Петербурге 9 января 1915 г. лишь «немногие предприятия» и примерно 2,5-2,7 тыс. рабочих «молчаливо» отметили эту дату ${ }^{48}$. Необходимо подчеркнуть, что медленное восстановление агитации в рабочей среде после разгрома партийных рабочих организаций в начале 1915 г. мало влияло на движение. В книге отмечен, скорее, «индифферентизм большинства рабочих» в связи с судом над арестованными депутатами-большевиками, намеченным на 10 февраля 1915 г. Малозаметный подъем стачечного движения все же в феврале был: в 2,5 раза по сравнению с январем выросло число стачечников, $75 \%$ составляли чисто экономи-

\footnotetext{
45 Кирьянов Ю. И. Указ. соч. С. 39-44.

46 Там же. С. 45-48. Автор книги считал, что показатели в литературе - 46,5 тыс. стачечников в связи с началом войны и 9,5 тыс. в связи с арестом думских депутатов-большевиков завышены. См.: Там же. С. 86.

47 Там же. С. 204.

48 Там же. С. 48.
}

DOI: $10.7256 / 2222-1972.2014 .3 .13745$

ческие стачки, писала и Б. Б. Граве ${ }^{49}$. День памяти жертв Ленского расстрела (1912 г.) в 1915 г. был отмечен только тремя стачками на приисках в Иркутской губернии ${ }^{50}$.

Заново проверив источники, Ю. И. Кирьянов сумел развенчать стремление в советские времена представить начало подъема политического рабочего движения ранее осени 1915 г. В литературе не было оговорок о «кратковременном» перерыве в работе (иногда перерыв в течение 1 часа считался стачкой). Тем не менее автор книги считает, что 1 Мая 1915 г. было «знаковым»: 62 политические стачки рабочих состоялись в обеих столицах и еще в 9 других городах ${ }^{51}$. В них участвовала небольшая часть рабочих в связи с условиями военного времени. В Петрограде тем не менее этот день впервые отметили рабочие на пяти заводах Военного и Морского ведомства. В Москве первомайская забастовка была отмечена на 15 предприятиях, в одном случае при выходе с завода после обеда рабочие пели «Марсельезу».

В ряду социально-политических протестов рабочих в условиях войны Ю. И. Кирьянов рассматривает и те, что были связаны с так называемым немецким засильем. Это - особая страница рабочей истории России. Ясно одно: как ни стремилась полиция отвлечь население от антиправительственных настроений в связи с затягиванием войны, антинемецкая кампания артикулировала круг острых социальных и экономических проблем, поворачивая их вектор в сторону критики правительства ${ }^{52}$.

Эта кампания оставила националистический «осадок», но в рабочем движении назрели другие события. Реакция на них, связанных с вооруженным подавлением стачек в Костроме (5-6 июня 1915 г.) и в Иваново-Вознесенске (10 августа 1915 г. $)^{53}$, вызвала волну сильного антиправительственного протеста. Борьба с хозяевами фабрик в Костроме за элементарные требования рабочих закончилась арестами и расстрелом фабричной толпы, 12 человек были убиты и 45 ранены. Начавшись с борьбы за повышение оплаты труда, стачки в Иваново-Возне-

\footnotetext{
49 Граве Б. Б. Указ. соч. С. 113.

50 Кирьянов Ю. И. Указ. соч. С. 49-50.

51 Петроград, Москва, Кострома, Сормово, Тверь, Самара, Ростов-на-Дону, Нахичевань, Рига, Харьков, Тифлис; кроме того - в селах Саратовской губернии, на копях Иркутской губернии и в Семипалатинской области. См.: Там же. С. 51-52.

52 Там же. С. 53-57.

53 Там же. С. 57-61.
} 


\section{Исторический журнал: научные исследования № 3 (21) • 2014}

DOI: $10.7256 / 2222-1972.2014 .3 .13745$

сенске были активно поддержаны значительной группой социал-демократов. И здесь они закончились массовыми арестами и расстрелом мирной демонстрации 10 августа 1915 г. 30 рабочих были убиты и 53 ранены. Ответом был подъем протестного движения в целом регионе. Общее число бастующих 69 предприятий, связанных с событиями в Костроме и Иваново-Вознесенске, составило 47,3 тыс. рабочих ${ }^{54}$. Эти забастовки демонстративно политического характера, с лозунгами «Долой!», с политическим речами ораторов не имели экономических требований, в них зазвучал протест против войны, и это был перелом в характере движения. Он подтверждался стачками солидарности в Петрограде, Москве, Нижнем Новгороде, Сормове, Туле, Харькове, Екатеринославе. В Петрограде они объединили 17-20 августа 1915 г. 20,4 тыс. рабочих 30 предприятий, став предвестником политических стачек в поддержку Государственной думы в связи со слухами о ее роспуске ${ }^{55}$.

В книге Ю. И. Кирьянова отмечено изменение вектора протестного рабочего движении в направлении борьбы с государственной системой. Уже в 20-х числах августа 1915 г. «во всех слоях населения... губернии стала проявляться некоторая нервозность и стремление искать виновников неудач... надежда на благоприятный исход войны в народе подорвана» ${ }^{56}$.

Ю. И. Кирьянов представляет неизвестный источник от 19 августа 1915 г. - листок с требованиями, предъявленными 1,5 тыс. рабочих верфи Путиловского завода в связи со слухами о роспуске Думы. На первом месте в них было требование освободить из ссылки членов Государственной думы и продлить ее деятельность. По этому поводу один из помощников начальника ГЖУ заметил: среди этих забастовщиков много таких, которые не понимают до конца смысла и значения Думы, но бессознательно считают, что она «существовать должна и что так будет лучше», что она может войти в их нужды и «облегчить положение». Антинемецкие настроения отразило требование «удалить германских и австрийских подданных, перешедших в русское подданство». Повседневность отражала решительная просьба «убрать казаков, охраняющих завод», «призвать в армию полицию из внутренних городов России и заменить

\footnotetext{
54 Кирьянов Ю. И. Указ. соч. С. 204.

55 Там же. С. 60-61.

56 Там же. С. 90.
}

ее инвалидами и теми лицами, которые неспособны идти на поле брани». Листок возвращал рабочих к демократическим лозунгам революции 1905 г. о свободе слова и всеобщем избирательном праве ${ }^{57}$.

За день до роспуска Думы в политическую забастовку включились 19,3 тыс. рабочих Путиловского завода, где стачка началась с лафетносборочной мастерской, как и в феврале 1917 г. В день указа о роспуске, 3 сентября, к путиловцам присоединились 45 тыс. рабочих Выборгского района, 4 сентября - 62 предприятия, изготовлявшие заказы Военного ведомства. Администрация Путиловского завода объявила расчет забастовщикам, но 5 сентября ее отрезвили угрозы отправить в армию большее число рабочих. Всего в сентябрьских политических стачках в столице на 60 предприятиях участвовали 70 тыс. рабочих ${ }^{58}$.

В Москве в сентябре 1915 г. в связи с роспуском Думы в городской политической стачке в рабочей забастовке участвовали 58,7 тыс. рабочих 162 предприятий ${ }^{59}$. На Страстной площади в ходе митинга произошло столкновение народа с полицией, 4 человека в толпе были убиты, ранены - 40 митинговавших и 25 полицейских.

Со 2 по 11 сентября в Петрограде и Москве в 169 стачках участвовали около 100 тыс. рабочих ${ }^{60}$. Особенностыю стачек были рост солидарности $^{61}$, участие в них рабочих предприятий, работавших на военные нужды. Тогда впервые прозвучал призыв большевиков к всеобщей политической забастовке, но он не был услышан рабочими ${ }^{62}$.

В 1916 г. забастовки в «табельные» для революционеров дни готовились не только большевиками, но и эсерами. В контексте критики советской историографии в книге Ю. И. Кирьянова уточнены данные о 62 стачках 9 января в 1916 г. и около 70 тыс. их участников, что почти в 5 раз превысило число стачек и в 22 раза - стачечников по сравнению с 9 января 1915 г. ${ }^{63}$.

61 В 1915 г. политические стачки были отмечены в Петрограде, Москве, Костроме, Иваново-Вознесенске, Сормове, Твери, Риге, Ростове-на-Дону, Нахичевани, Саратове. См.: Там же. C. 87.

62 Там же. С. 66.

63 Там же. С. 67-68, 204.
} 


\section{Историография и источниковедение}

В феврале 1916 г. волнения рабочих Путиловского завода начались со стачки в одном из цехов, с требований повысить заработную плату на $70 \%$. Отказ привел к прекращению работы в знак солидарности всех мастерских завода и более 20 тыс. человек. Завод был закрыт для нового набора. С 29 февраля по 3 марта в столице прошли стачки солидарности на 49 предприятиях, на некоторых была заметна агитация большевиков и эсеров; в них участвовали более 73 тыс. рабочих ${ }^{64}$. С этого времени в стране число участников политических стачек стало расти за счет новых предприятий. Поводом почти везде становится агитация партийных функционеров. В апреле 1916 г. память о Ленских событиях 1912 г. в Петрограде поддержали более 8 тыс. распропагандированных рабочих военных заводов 65 .

День 1 мая в 1916 г. совпал с воскресеньем. Ю. И. Кирьянов доказал (идя против представления о непрерывном подъеме политического протеста в советской историографии), что стачки в этот день состоялись только в Петрограде (одна стачка) и Москве (3 стачки). В других случаях в 7 забастовках 2-5 мая 1916 г. рабочие выдвигали экономические требования ${ }^{66}$.

В итоге, по Кирьянову, 1916 г. в целом дал 252 политические стачки против 355 в 1915 г., но 273,1 тыс. стачечников против 165,2 тыс. в 1915 г., т. е. почти на $30 \%$ больше 67 . В 1916 г. возросло и число населенных пунктов, где были отмечены стачки.

Осенью 1916 г. протестное движение локализуется в Петрограде, становясь объектом активной пропаганды коллективных действий. В начале этого процесса - продовольственные затруднения, а в политическом отношении - протест против суда над кронштадтскими матросами. Фабричная инспекция выделила столицу как разгоравшийся очаг рабочего движения. Она отметила в октябре 119 забастовок политического характера и 138,5 тыс. участников в них, а в Петроградской губернии - 115 забастовок и 138,0 тыс. участников ${ }^{68}$. Забастовки в Петрограде имели две волны: 17-19 и 26-31 октября - и

\footnotetext{
64 Кирьянов Ю. И. Указ. соч. С. 69.

65 Там же. С. 69-70.

66 Критике автора книги за превышение показателей стачек подверглись работы по Грузии (не было там «мощной волны»), Уралу, Москве и т. д. См.: Там же. С. 71-74.

67 См.: Там же. С. 570-574.

68 По подсчетам Ю. И. Кирьянова - 110 забастовок и 132,9 тысяч участников. См.: Там же. С. 214.
}

начались на Выборгской стороне на фоне продовольственных затруднений. О недовольстве политикой правительства и войной громко заявили металлисты. 19 октября, в один день, забастовали 44 предприятия и почти 60 тыс. рабочих $^{69}$. Тревожным предзнаменованием для правительства был «симптом разложения армии» - «приветствие» солдатами 181-го пехотного полка забастовавших рабочих, которые, «выходя с завода «Рено» на полотно Финляндской ж.д., запели «Марсельезу». Солдаты как бы становились участниками общего с рабочими события $^{70}$. На углубление кризиса указывал и однодневный (19 октября) политический протест в Москве более 16 тыс. рабочих 23 предприятий в связи со слухами о роспуске Государственной думы $^{71}$.

Новый подъем забастовочного движения через неделю (26-31 октября) был уже целиком связан с активной пропагандой коллективных действий большевиками. Именно ПК РСДРП призвал продолжить борьбу до всеобщей забастовки «в знак союза революционного народа и революционной армии», избрав их поводом защиту представших перед царским судом матросов Кронштадтской военной организации. Некоторые рабочие коллективы повторили стачку; а другие, ранее не бастовавшие, поддержали политический призыв ${ }^{72}$.

Рубеж 1916-1917 гг. был новой фазой протестного рабочего движения, формирующего идейное и радикальное противостояние уже государственной системе в целом. С этого времени требования «Хлеба!» к правительству трансформировались к его способности обеспечить население продуктами и предметами первой необходимости. При увеличении массовости движения вырисовывалось его ядро, утверждалось место рабочих выступлений в самой гуще социально-политических протестов в российском обществе. Они стали усиливаться как никогда ранее антивоенной направленностью движения. «Увеличения заработной платы, периодически делаемые рабочим предпринимателями, далеко не поспевают за ростом дороговизны, вследствие чего степень нужды не понижается и рабочий, недоедая и страдая от холода, естественно, чужд соображений, заставляющих

\footnotetext{
69 Там же. С. 196-197.

70 Там же. С. 91.

71 Там же. С. 76.

72 Там же. С. 196-199.
} 


\section{Исторический журнал: научные исследования № 3 (21) • 2014}

DOI: 10.7256/2222-1972.2014.3.13745

продолжать войну... Два описанных условия в итоге дают нескрываемое желание скорейшего мира ${ }^{73}$, - отмечают документы местных ГЖУ. В организуемых социалистами стачках экономические требования выдвигаются как повод для политического протеста.

12-я годовщина Кровавого воскресенья была отмечена 9-13 января уже 214 стачками и более 196,3 тыс. участников, что превышало показатели 1916 г., связанные с известной датой в Петрограде и Москве, соответственно в 3,5 и 2,8 раза ${ }^{74}$. В 1917 г. эти стачки проходили одновременно с протестами против отсрочки открытия Государственной думы. В Петрограде бастовали 114 предприятий и 144,7 тыс. рабочих, т. е. 53 и $73 \%$ от общего числа в стране. Стачки по поводу 9 января в Москве отметили 36,8 тыс. рабочих 76 предприятий и рабочие еще в 12 городах. Везде отчетливо звучали протесты против дороговизны и лозунг «Хлеба!» ${ }^{75}$. Охранка отмечала подъем стачек в связи и с утомлением войной, и с массой разнообразных слухов, волнующих население. По полицейским документам в новых стачках была заметна роль и социалдемократов, и эсеров, и анархистов, а на сопровождавших забастовки собраниях - и представителей Рабочей группы ЦВПК.

В обстановке открытого массового недовольства экономическим положением существенно менялось отношение к Государственной думе. Возмущение рабочих по поводу нехватки продовольствия связывалось с надеждой на ее помощь в решении наболевших вопросов. Уловив это, Рабочая группа ЦВПК во главе с рабочим-менышевиком К. А. Гвоздевым 12 января призвала рабочих поддержать идею открытия Думы и одновременно озвучить свои требования. В ночь на 27 января инициаторы призыва ${ }^{76}-$ члены рабочих групп ЦВПК и Петроградского областного ВПК - были арестованы за подготовку шествия к Думе в день ее открытия.

\footnotetext{
73 Кирьянов Ю. И. Указ. соч. С. 90-91.

74 Там же. С. 78, 204-205. Подсчеты наши. - И. П. Цифру 300 тыс. забастовщиков автор книги считает завышенной. Цифра 150 тыс. участников в 1917 г. была принята в советской историографии.

75 Там же. С. 124-125.

76 В этом призыве говорилось, что «режим самовластия душит страну», что утомленная Россия ждет мира, что сегодня забастовки недостаточно, а сотни тысяч рабочих со всех концов города должны «никого не задевая <...> не вызывая полицию и насилие», двинуться к Государственной думе и немедленно «учредить Временное революционное правительство». Оно должно, опираясь на народ, вывести страну из тупика и гибельной разрухи, укрепить политическую свободу и привести к миру. См.: Меньшевики в 1917 году. М., 1994. Т. 1. С. 112.
}

Большевики попытались опередить меньшевиков. Русское бюро ЦК решило отметить вторую годовщину суда над думскими депутатами начиная с 10 до 13 февраля (12 февраля, когда в 1915 г. царский суд отправил депутатовбольшевиков в ссылку в Сибирь, приходилось на воскресенье). В книге впервые сказано о том, к чему безотчетно привела общая агитация и большевиков, и гвоздевцев, т. е. меньшевиковоборонцев. По подсчетам Ю. И. Кирьянова, 10-14 февраля в Петрограде в 79 забастовках с собраниями участвовали более 104,3 тыс. рабочих $^{77}$. В Москве с протестом против ареста членов военно-промышленных комитетов 14 февраля в политических стачках участвовали 12,5 тыс. рабочих 16 предприятий ${ }^{78}$.

Показательно, что в Петрограде доля участников стачек, требовавших повышения заработной платы в январе и в наступающем феврале 1917 г., падает до 10\%, тогда как в 1916 г. она составляла 54\%. Доля участников политических стачек поднимается до 85\%, тогда как в 1916 г. она составляла $33 \%^{79}$.

Поставив проблему нарастания социально-политического протеста рабочих России в годы Первой мировой войны, Ю. И. Кирьянов не мог обойти тему уличных демонстраций, которые, как известно, в определенных условиях могут быть направлены против господствующих институтов власти, против существующей системы государственного устройства. В немногих демонстрациях в России в условиях военного времени отражались социальная напряженность и настроение масс, крепла солидарность в борьбе за социально-экономические требования и политические свободы. С 19 июля 1914 г. по 22 февраля 1917 г. 52 демонстрации в их «классической форме» представлены в книге так: в 1914 г. - 3; в 1915 г. -11 ; в 1916 г. - 20; в начале 1917г. - 18. Начало революции - 23-24 февраля 1917 г. - 69 случаями демонстраций (по подсчетам автора) «перекрыло» это число ${ }^{80}$.

Политические демонстрации возникли в первые дни после объявления войны 19 июля 1914 г. в Петербурге. Небольшие демонстрации в сочетании со стачками в 1915 г. состоялись в Москве 1 мая, в Иваново-Вознесенске - в августе,

\footnotetext{
77 Кирьянов Ю. И. Указ. соч. С. 205.

78 Там же. С. 82-84.

79 Там же. С. 27.

80 Там же. С. 129, 208. Под «классической формой» подразумевается атрибутика - красные флаги, транспаранты, лозунги, пение революционных песен.
} 


\section{Историография и источниковедение}

DOI: $10.7256 / 2222-1972.2014 .3 .13745$

в связи с роспуском Думы - в начале сентября 1915 г. и похоронами в Саратове - в ноябре. В 1916 г. в связи с 9 января 1905 г. коллективный протест против репрессий вылился в небольшие демонстрации, такие же как в октябре, по поводу дороговизны продуктов питания и т. д. ${ }^{81}$. Выступления на аналогичной почве были и в начале 1917 г. 9-12 января в Москве и 16 января - в Харькове.

Предреволюционная волна политических рабочих демонстраций приходилась на 14 февраля в Петрограде в день возобновления работы Думы. Небольшие демонстрации (не более 200 участников) тогда прошли под лозунгами «Долой войну!», «Долой правительство!», «Да здравствует вторая революция!», «Да здравствует республика!». Это были лозунги большевиков, которые распространили в те дни около 1 тыс. листовок. В революцию демонстрации начали с лозунгов «Хлеба!» и «Долой войну!», ставших в Петрограде и Москве основой глобального революционно-политического процесса.

\section{По пути освобождения от навязчивых схем и догм}

В книге Ю. И. Кирьянова как бы пунктиром намечены темы и связанные с ними проблемы, которые должны лечь в основу пересмотра прежних представлений о социально-политическом протесте рабочих России в годы Первой мировой войны.

История рабочего движения в советской историографии имела жесткий идеологический контекст. Она никогда не была нейтральной, а только связанной для дореволюционного периода с большевистской партией. В книге Ю. И. Кирьянова «рабочая тема» оказалась самостоятельной, освобожденной от истории КПСС, скомпрометированной в 1990-е гг.

Проработав огромный комплекс источников, автор книги в целом придерживался мнения современников, а также историков 1920-х гг, также бывших свидетелями и очевидцами событий в стране в годы войны. Его вывод как исследователя однозначен: партийное руководство политическими стачками продолжительное время осуществлялось исключительно большевиками, которые последовательно «работали на революцию». Социал-демократы с первых дней войны, опасаясь быть непонятыми массой

81 Кирьянов Ю. И. Указ. соч. С. 115-123. рабочих, отнюдь «не влачили жалкое существование», как писалось в отчете ПОО, а «осторожно вели агитацию в пользу политических выступлений» ${ }^{82}$. Меньшевики-оборонцы в начале войны отрицательно относились к стачкам, которые, по их мнению, могли повредить делу обеспечения обороны страны.

Ю. И. Кирьянов отмечает интерес к политическим стачкам трудовой фракции Думы и ее лидера А. Ф. Керенского. И Департамент полиции «правильно считал», что начавшиеся в августе 1915 г. на политической почве забастовки являются «результатом революционной деятельности социал-демократической и трудовой фракции Государственной думы», а в ней - «главным образом лидера последней присяжного поверенного Керенского» 83 . В ходе углубления экономического и политического кризиса активизировалось и стремление меньшевиков-ликвидаторов вместе с трудовиками и эсерами использовать массовые выступления рабочих в поддержку Думы.

В книге подчеркнуто, что военные условия вносили изменения в содержание партийной пропаганды и агитации, поведение социалистических партий. Перед февралем 1917 г. большевики в Петрограде неоднократно обсуждали тактические вопросы с представителями других левых партий и групп. Не хватало сил в агитации, чтобы стачки отличались широтой постановки политических требований, а не «привязывались к месту события» 84 . В листовках большевиков встречается как политический лозунг 8-часового рабочего дня, но не он стал поводом для выступлений ${ }^{85}$. В советской историографии замалчивались огромные трудности, которые испытывали большевики в повседневной работе, провалы в задуманном. Ю. И. Кирьянов объясняет это недостатком листково-прокламационной литературы. Партийная пропаганда и агитация большевиков в конце 1916 - начале 1917 гг. были несопоставимыми с массовыми выступлениями на почве продовольственного кризиса.

Агитация большевиков в прокламациях часто не достигала цели, так как не отвечала на-

\footnotetext{
82 Там же. С. 96

83 А. Ф. Керенский рекомендовал тогда рабочим устраивать массовки на улицах, на заводах, создавать коллективы для образования, как в 1905 г., Совета рабочих депутатов, чтобы «в известный момент направить движение на созыв Учредительного собрания». См.: Там же. С. 97.

84 Там же. С. 94.

85 Там же. С. 93. Требование 8-часового рабочего дня выдвигалось как экономическое на предприятиях с непрерывным производственным циклом.
} 


\section{Исторический журнал: научные исследования № 3 (21) • 2014}

DOI: 10.7256/2222-1972.2014.3.13745

строению рабочих. Нереальным оказался перевод «на политические рельсы» стачек в 1915 г. в Костроме и Иваново-Вознесенске. В Петрограде в годовщину 9 января в 1916 г. сорвались превращение однодневной забастовки в общеполитическую и организация уличных выступлений. Не была услышана рабочими в феврале 1916 г. принятая әсерами идея большевиков поддержать путиловцев всеобщей стачкой и уличными демонстрациями, так же как призыв большевиков к всеобщей политической стачке в столице в октябре 1916 г. Но вместо победных реляций о роли большевиков в рабочем движении, присущих советской литературе, автор книги обращает внимание на последовательность и устремленность, с какой социал-демократы продвигались к намеченной цели. В агентурных записках по общественному движению в Петрограде в январе 1917 г. отмечалось, что в конечном итоге «идея всеобщей забастовки день ото дня приобретала новых сторонников и становилась популярной» ${ }^{86}$. Призыв к всеобщей политической забастовке 26 февраля 1917 г. и сыграл, возможно, решающую роль в победе революции.

Перед 14 февраля 1917 г. обнаружилась непроходимая пропасть между принявшими открытые массовые выступления рабочих трудовиками, эсерами, даже менышевиками-ликвидаторами, с одной стороны, и кадетами - с другой. Ю. И. Кирьянов обращает внимание на то, что накануне 14 февраля 1917 г. кадет П. Н. Милюков, как и командующий военным округом генерал С. С. Хабалов, обратившийся к рабочим с призывом оставаться у станков, просил их не выходить на улицу, «не омрачать возобновление занятий Думы действием, которое вселит в умы смуту» ${ }^{87}$. Убийственно для характеристики кадетов упоминание о правых партиях и их организациях (они были на ряде предприятий в Петрограде, Москве, Екатеринославе и др. городах), которые крайне отрицательно относились к массовым выступлениям, считая, что они подрывают обороноспособность страны ${ }^{88}$.

Исследование Ю. И. Кирьянова выявляет перспективные темы, требующие дальнейшей разработки. Например, изменение состава рабочего класса в годы Первой мировой войны, которое было сложным процессом. Марксистско-ленинская концепция «мыслила» классо-

\footnotetext{
86 Кирьянов Ю. И. Указ. соч. С. 99-101.

87 Там же. С. 99.

88 Там же.
}

выми количественными категориями. Недифференцированные показатели не учитывали особенностей военного времени, изменения роли отдельных отраслей производства, отличия в составе рабочих на военных предприятиях. Определение состава рабочих в советской историографии было зациклено на ленинских работах о «мелкобуржуазной волне, захлестнувшей сознательный пролетариат». Было принято «чернить» выходцев из городских мелкобуржуазных слоев, занимавших рабочие места в расчете на отсрочки от армии на оборонных предприятиях, «растворявших» рабочие коллективы «идейной отсталостью», хотя и раньше высказывались сомнения по поводу некорректности таких представлений ${ }^{89}$.

Ю. И. Кирьянов разделил точку зрения А. Л. Сидорова, И. П. Лейберова, О. И. Шкаратана ${ }^{90}$ и других историков, склоняясь к тому, что состав промышленного пролетариата в Петрограде к февралю 1917 г. не менялся настолько, насколько его стремилась представить советская литература, «оправдывая» появление кадетского Временного правительства.

Это выход на проблему, которая до конца не решена в науке, - о соотношении стихийности, организованности и уровня сознательности рабочих, участников движения. Сегодняшние историки состав социально-политического протестного рабочего движения представляют «сборищем людей», «сеявших смуту» «с элементами запредельной бунтарской страсти» ${ }^{91}$.

Ю. И. Кирьянов считал, что доля рабочих крупных промышленных предприятий, связанных с военным производством, призванных в армию (в конечном счете они в Петрограде «делали погоду» в развитии стачечного движения $\left.{ }^{92}\right)$, была невелика даже после того,

\footnotetext{
89 Выяснилось, что на всех военных предприятиях в Петрограде выходцев из городских средних слоев, спасавшихся от армии, было не более 7\%, и это считалось преувеличением. См.: Лейберов И. П., Шкаратан О. И. К вопросу о составе петроградских промышленных рабочих в 1917 г. // Вопросы истории. 1961. № 1. С. 47-51.

90 Кирьянов Ю. И. Социально-политический протест. С. 28; Сидоров А. Л. Указ. соч. С. 410-423; Лейберов И. П. На штурм самодержавия. М., 1979. С. 18-19; Лейберов И. П., Шкаратан О. И. Указ. соч. С. 47-51.

91 Можно считать это случайным, но в фундаментальном труде В. П. Булдакова упоминаются только работы Ю. И. Кирьянова о массовых выступлениях в войну на почве дороговизны. См.: Булдаков В. П. Красная смута. М., 2010. С. 141, 143, $746,745$.

92 Абсолютное большинство стачечников в период войны было занято на предприятиях, обслуживавших армию и флот. См.: Кирьянов Ю. И. Указ. соч. С. 25.
} 


\section{Историография и источниковедение}

DOI: $10.7256 / 2222-1972.2014 .3 .13745$

как началась отправка в армию за участие в стачках. Многие кадровые рабочие, которым по возрасту грозила мобилизация, получали отсрочки от призыва, сохраняли свои места на предприятии.

Неправомерно преувеличивать влияние на поведение рабочих в ходе массовых протестов увеличения в их составе рабочих-женщин и подростков и при этом не учитывать усиление пропаганды коллективных действий со стороны социалистических партий. Половая и возрастная стратификация общества преломляется в различных условиях. Необходимо учитывать и процесс социализации всего общества, который усилился в революционный период.

Движение 23 февраля 1917 г., заканчивает исследование темы Ю. И. Кирьянов, «началось без партийных призывов» партийных организаций, они появились лишь 25 и 26 февраля ${ }^{93}$. Но в революционные дни в Петрограде крупнейшие военные металлообрабатывающие предприятия стали важнейшими центрами во всеобей стачке. Все началось 17 февраля с Путиловского завода, а 25-26 февраля рабочие-металлисты составляли $71,5 \%$ от участников всеобщей стачки, задавали тон рабочим колоннам демонстраций, представлявшим крупные заводы и районы Петрограда ${ }^{94}$. В рабочую среду этих предприятий устремлялись с начала войны партийные пропагандисты и агитаторы.

Вряд ли можно назвать «истлевшим театральным реквизитом» ${ }^{95}$ участие во всеобщей стачке 26 февраля 1917 г. рабочих 438 предприятий столицы, на 11 из которых трудились свыше 1000 лиц наемного труда. Социально-политический протест рабочих России в феврале
1917 г. был не «массовкой»96, а зрелой в социальном смысле средой, где начали возникать фабрично-заводские комитеты, где выборами Совета рабочих депутатов при наличии организационного ядра начался закономерный для революции процесс приспособления массового движения к социальным институтам.

Либеральная газета «Русское слово» от 2 марта 1917 г. в обзоре февральских событий отмечала: «С 25 февраля движение приняло уже более организованный характер. В нем приняли участие организованные группы рабочих... (их) особые комитеты». В стихийном движении масс эти организационные «вкрапления» придавали движению сплоченность и целеустремленность. Они оказали решающее влияние и на солдатские массы, вступившие в борьбу и вместе с рабочими устремившиеся 27 февраля к Государственной думе, ставшей две недели назад центром рабочего движения, чего, правда, не заметили ее депутаты и председатель - октябрист М. В. Родзянко. Последний, как известно, воскликнул: «Сделали меня революционером! Сделали!» 97

В своей книге Ю. И. Кирьянов, во-первых, показал, что прежде чем осуществлять прорыв в историографии, необходима ревизия существующей информационной базы исследования темы. Во-вторых, он доказал, что, ставя задачу освободиться от навязчивых постулатов, следует тем не менее учитывать фактор преемственности в историографическом процессе. Ю. И. Кирьянов надеялся, что в новых условиях история будет востребована как идеологическая задача - но такая задача, которая не станет подчинять себе историка. И в этом - значение его последнего труда.

\section{Библиография:}

1. Булдаков В. П. Красная смута. М., 2010.

2. Граве Б. Б. К истории классовой борьбы в России в годы империалистической войны. Июль 1914 - февраль 1917 гг. Пролетариат и буржуазия. М.-Л., 1926.

3. История рабочих Ленинграда. Том I. 1703 - февраль 1917. Л., 1972.

4. Кирьянов Ю. И. Социально-политический протест рабочих России в годы Первой мировой войны (июль 1914 - февраль 1917 гг.). М., 2005.

5. Крылова И. И. К вопросу о статистике стачек в годы Первой мировой войны // Из истории империализма в России. М.-Л., 1959.

6. Лейберов И. П. На штурм самодержавия. М., 1979.

7. Лейберов И. П. О революционных выступлениях петроградского пролетариата в годы Первой мировой войны и Февральской революции // Вопросы истории. 1964. № 2.

8. Лейберов И. П., Шкаратан О. И. К вопросу о составе петроградских промышленных рабочих в 1917 г. // Вопросы истории. 1961. № 1.

93 Кирьянов Ю. И. Там же. С. 151.

94 Лейберов И. П. На штурм самодержавия... С. 190-191.

95 Булдаков В. П. Указ. соч. С. 141.

\author{
96 Там же. С. 17. \\ 97 Родзянко М. В. Государственная дума и Февральская рево-
} люция 1917 года. Ростов-на-Дону, 1919. С. 39-40. 


\section{Исторический журнал: научные исследования № 3 (21) • 2014}

DOI: $10.7256 / 2222-1972.2014 .3 .13745$

9. Минц И. И. История Великого Октября. Т. 1. Свержение самодержавия. М., 1967.

10. Никонов В. А. Крушение России. 1917. Минск, 2011.

11. Прошлое крупным планом. Современные исследования по микроистории. СПб., 2003.

12. Пушкарева И. М. Февральская буржуазно-демократическая революция 1917 г. в России. М., 1982.

13. Рабочее движение в России в годы войны. М., 1925.

14. Рабочий класс России. 1907 - февраль 1917. М., 1982.

15. Россия в мировой войне. 1914-1918. (В цифрах). М., 1925.

16. Статистический сборник за 1913-1917 гг. // Труды ЦСУ. Т. VII. Вып. 1. М., 1921.

17. Стачечное движение в России в годы Первой мировой войны. Материалы официальной статистики за август 1914 январь 1917 гг.: В 4-х выпусках / Отв. ред. В. Я. Лаверычев. М., 1987.

18. Струмилин С. Г. Проблемы экономики труда. М., 1926.

19. Трудовые конфликты и рабочее движение в России на рубеже XIX - начала XX вв. / Отв. ред. И. М. Пушкарева. СПб., 2011.

20. Фабрично-заводская промышленность в период 1914-1918 гг. М., 1923.

21. Флеер М. Г. Рабочее движение в России в годы империалистической войны. Л., 1926.

22. Яковлев Я. А. Февральские дни 1917 г. // Пролетарская революция. 1927. № 2-3.

23. Яковлева К. Н. Забастовочное движение в России за 1895-1917 гг. // Материалы по статистике труда. Вып. 8. М., 1920.

\section{References (transliterated):}

1. Buldakov V. P. Krasnaya smuta. M., 2010.

2. Grave B. B. K istorii klassovoi bor'by v Rossii v gody imperialisticheskoi voiny. Iyul' 1914 - fevral' 1917 gg. Proletariat i burzhuaziya. M.-L., 1926.

3. Istoriya rabochikh Leningrada. Tom I. 1703 - fevral' 1917. L., 1972.

4. Kir'yanov Yu. I. Sotsial'no-politicheskii protest rabochikh Rossii v gody Pervoi mirovoi voiny (iyul' 1914 - fevral' 1917 gg.). M., 2005.

5. Krylova I. I. K voprosu o statistike stachek v gody Pervoi mirovoi voiny // Iz istorii imperializma v Rossii. M.-L., 1959.

6. Leiberov I. P. Na shturm samoderzhaviya. M., 1979.

7. Leiberov I. P. O revolyutsionnykh vystupleniyakh petrogradskogo proletariata v gody Pervoi mirovoi voiny i Fevral'skoi revolyutsii // Voprosy istorii. 1964. № 2.

8. Leiberov I. P., Shkaratan O. I. K voprosu o soctave petrogradskikh promyshlennykh rabochikh v 1917 g. // Voprosy istorii. 1961. № 1.

9. Mints I. I. Istoriya Velikogo Oktyabrya. T. 1. Sverzhenie samoderzhaviya. M., 1967.

10. Nikonov V. A. Krushenie Rossii. 1917. Minsk, 2011.

11. Proshloe krupnym planom. Sovremennye issledovaniya po mikroistorii. SPb., 2003.

12. Pushkareva I. M. Fevral'skaya burzhuazno-demokraticheskaya revolyutsiya 1917 g. v Rossii. M., 1982.

13. Rabochee dvizhenie v Rossii v gody voiny. M., 1925.

14. Rabochii klass Rossii. 1907 - fevral' 1917. M., 1982.

15. Rossiya v mirovoi voine. 1914-1918. (V tsifrakh). M., 1925.

16. Statisticheskii sbornik za 1913-1917 gg. // Trudy TsSU. T. VII. Vyp. 1. M., 1921.

17. Stachechnoe dvizhenie v Rossii v gody Pervoi mirovoi voiny. Materialy ofitsial'noi statistiki za avgust 1914 - yanvar' 1917 gg.: V 4-kh vypuskakh / Otv. red. V. Ya. Laverychev. M., 1987.

18. Strumilin S. G. Problemy ekonomiki truda. M., 1926.

19. Trudovye konflikty i rabochee dvizhenie v Rossii na rubezhe XIX - nachala KhKh vv. / Otv. red. I. M. Pushkareva. SPb., 2011.

20. Fabrichno-zavodskaya promyshlennost' v period 1914-1918 gg. M., 1923.

21. Fleer M. G. Rabochee dvizhenie v Rossii v gody imperialisticheskoi voiny. L., 1926.

22. Yakovlev Ya. A. Fevral'skie dni 1917 g. // Proletarskaya revolyutsiya. 1927. № 2-3.

23. Yakovleva K. N. Zabastovochnoe dvizhenie v Rossii za 1895-1917 gg. // Materialy po statistike truda. Vyp. 8. M., 1920. 